\title{
LEMAHNYA BADAN PERMUSYAWARATAN DESA (BPD) DALAM MELAKSANAKAN FUNGSI PEMERINTAHAN DESA (Studi Desa Tegalwangi Kecamatan Menes Kabupaten Pandeglang)
}

\author{
Ombi Romli \\ Elly Nurlia \\ Program Studi Ilmu Pemerintahan \\ Fakultas Ilmu Sosial dan Ilmu Politik Universitas Mathla'ul Anwar \\ Email: ombi.sc10601@gmail.com
}

\begin{abstract}
ABSTRAK
Selama ini yang terjadi proses pelaksanaan pemerintahan desa di Indonesia lebih terfokus pada kepala desa dan perangkat desa. Padahal dalam Undang-Undang Nomor 6 Tahun 2014 Tentang Desa, dinyatakan bahwa yang menjalankan fungsi pemerintahan desa bukan hanya Kepala Desa, tetapi juga Badan Permusyawaratan Desa (BPD). Keadaan ini terjadi karena secara umum Badan Permusyawaratan Desa masih lemah dalam melaksanakan fungsi pemerintahan desa jika dibandingkan dengan kepala desa dan perangkatnya. Seperti yang terjadi di desa Tegalwangi Kecamatan Menes Kabupaten Pandeglang Provinsi Banten. Tulisan ini bertujuan untuk mengetahui faktor-faktor lemahnya Badan Permusyawaratan Desa (BPD) Tegalwangi dalam melaksanakan fungsi pemerintahan desa. Metode yang digunakan dalam penelitian ini deskriptif dengan pendekatan kualitiatif, sedangkan pengumpulan data melalui observasi, wawancara, dan studi pustaka. Hasilnya menunjukan bahwa faktor-faktor yang menyebabkan lemahnya Badan Permusyawaratan Desa (BPD) Tegalwangi adalah : Pertama kurangnya kapasitas Sumber Daya Manusia BPD, kedua, sarana pendukung kerja Badan Permusyawaratan Desa kurang memadai, ketiga, pendapatan atau tunjangan anggota BPD yang kecil, dan keempat; belum adanya kebijakan yang dapat menguatkan posisi BPD dalam melaksanakan fungsinya.
\end{abstract}

Kata Kunci: Badan Permusyawartan Desa, Fungsi pemerintah Desa, Desa Tegalwangi

\section{ABSTRACT}

This happened during the implementation the village government process in Indonesia more has centered the village head and official village. Whereas in Law No. 6 of 2014 About the Village, stated that performing governmental functions it not only the village chief village, but also the Village Consultative Body. This occurs condition because of the general Village Consultative Body is still weak in carrying out the functions of the village government when compared with the village head and the official village. As happened in the village Tegalwangi district Menes, Regency Pandeglang Banten Province. This paper aims to determine the factors of weak Village Consultative Body (BPD) Tegalwangi in carrying out the functions of the village government. This Research use descriptive method with qualitative approach, while collecting data through observation, indepth interviews, and literature studies. The result showed that the factors that led to weak Village Consultative Body (BPD) Tegalwangi are: First lack of capacity of Human Resources BPD, a second, a means of supporting employment Village Consultative Body 
inadequate, third, income or benefits in the BPD were small, and the fourth; the absence of policies that can strengthen the position of BPD in carrying out its functions.

Keywords: Village Consultative Body, the function of the village government, Village Tegalwangi

\section{PENDAHULUAN}

Pemerintahan desa merupakan bagian yang tidak terpisahkan dalam penyelenggaraan Negara Kesatuan Republik Indonesia (NKRI). Sebagai pelaksana pemerintahan negara yang paling bawah yang bersentuhan langsung dengan masyarakat, pemerintah desa memiliki peran strategis sebagai ujung tombak dalam mencapai tujuan negara sebagaimana diamanatkan konstitusi.

Seperti halnya pada pemerintah pusat dan pemerintah daerah, penyelenggaraan pemerintahan desa juga dilengkapi dan dijalankan oleh lembaga pemerintahan yaitu lembaga eksekutif dan lembaga legislatif. Lembaga eksekutif dipegang oleh kepala desa dan perangkatnya, dan lembaga legislatif dipegang oleh Badan Permusyawaratan Desa (BPD)

Tetapi selama ini yang terjadi proses penyelenggaraan pemerintah desa lebih terfokus pada lembaga pemerintah desa yaitu kepala desa dan perangkatnya. Padahal dalam aturan perundangan dinyatakan bahwa yang menjalankan fungsi pemerintahan desa itu bukan hanya Kepala Desa, tetapi juga Badan Permusyawartan Desa (BPD).

"Badan Permusyawaratan Desa (BPD) merupakan lembaga yang melaksankan fungsi pemerintahan desa yang anggotanya merupakan wakil dari penduduk desa berdasarkan keterwakilan wilayah dan ditetapkan secara demokratis." (UU No 6 Tahun 2014 Tentang Desa Pasal 1)

Dalam sistem pemerintahan desa, pemerintahan desa akan berjalan efektif apabila unsur-unsur atau lembaga-lembaga penyelanggara pemerintahan desa dapat berjalan dengan baik. Jika unsur atau ada bagian dari sistem penyelengara pemerintahan desa tidak mampu melaksanakan tugas dan fungsinya sesuai dengan aturan perundang-undangan maka akan menghambat jalannya pemerintahan desa.

Dibandingkan dengan Kepala Desa, lembaga Badan Permusyawaratan Desa (BPD) pada umumnya masih dinilai lemah, belum dapat sepenuhnya menjalankan tugas dan fungsinya dengan baik sesuai dengan aturan perundang-undangan. Seperti yang ditujukan dari hasil penelitianpenelitian tentang Badan Permusyawaratan Desa (BPD) sebelumnya yaitu sebagai berikut : Pertama; penelitian Sartika Putri Ngadi dalam jurnal ejornal.unsrat.ac.id yang berjudul Peran Badan Permusyawatan Desa Dalam Menjalankan Fungsi Pengawasan Pemerintahan Di Desa Lopana Kecamatan Amurung Timur Kabupaten Minahasa Selatan. Hasil penelitian ini menunjukan bahwa Peran Badan Permusyawaran Desa (BPD) Lopana dalam menjalankan fungsi pengawasan Peraturan Desa 
dan Anggaran Pendapatan Belanja desa tidak dilaksanakan dengan baik (Sartika Putri Ngadi : 2014).

Kedua; penelitian Rico Masura dalam Jurnal Politico dengan judul Pelaksanaan Fungsi Badan Permusyawaratan Desa (BPD) Dalam Penyelengaraan Pemerintahan Desa (Suatu Studi Di Desa Bolangitang Satu Kecamatan Bolangitang Barat Kabupaten Bolaang Mongdow Utara).

Hasil penelitian ini menunjukan bahwa pelaksanaan fungsi Badan Permusyaratan Desa (BPD) di Desa Bolangitang dalam melaksanakan pemerintahan desa masih lemah. Bahkan boleh dikatakan dalam pelaksanaan sistem pemerintahan desa di Desa Bolangitang Badan Permusyaratan Desa (BPD) tidak mampu memberikan pengaruh pada peningkatan kerja pemerintah desa. (Rico Masura : 2014)

Ketiga; penelitian Yuniarti (dalam ejurnal umrah.ac.id) dengan judul Penilaian Kinerja Badan Permusyawaran Desa (BPD) di Desa Risun Kecamatan Lingga Utara Kabupaten Lingga. Hasil penelitian ini menunjukan kinerja Badan Permusyawaratan Desa (BPD) belum dapat menjalankan tugas dan fungsi mereka sebagaimana mestinya. Karena BPD tidak maksimal dalam menjalankan tugas dan fungsi mereka dalam melaksanakan tugas yang diemban. Tugas dan fungsi BPD tidak diserap secara luas oleh masyarakat, sehinga keberadan BPD tidak dipandang oleh masyarakat, dan menyebabkan timbulnya anggapan negatif terhadap BPD. BPD dinilai tidak bekerja oleh Masyarakat (Yuniarti : 2014)
Dengan mengacu pada ketiga hasil penelitian tersebut menunjukan bahwa pada umumnya kondisi lembaga Badan Permusyawaratan Desa (BPD) di Indonesia masih lemah dalam mejalankan fungsi pemerintahan desa. Padahal dalam penyelenggaraan pemerintahan diperlukan keseimbangan kekuatan (check and balance) antara kepala desa dan perangkatnya sebagai lembaga yang menjalakan fungsi eksekutif dengan Badan Permusyawaratan Desa (BPD) sebagai lembaga yang menjalankan fungsi legislatif.

Check and Balances lahir dari konsep trias politica yang dicetuskan pertama kali oleh John Locke ke (1632-1704) dan Montequieu (16891755) yang beranggapan bahwa kekuasaan negara harus dibagi menjadi kekuasaan eksekutif, kekuasaan legislatif, dan kekuasaan yudikatif. Check and balances (pengawasan dan keseimbangan) merupakan sebuah formula untuk membendung agar masing-masing kekuasaan dalam lembaga negara tidak melampaui batas kekuasaanya dimana setiap cabang kekuasaan dapat mengawasi dan mengimbangi cabang kekuasaan lainnya.

Pengertian

eksekutif berkenaan dengan pengurusan atau pengelolaan pemerintahan. Kekuasaan eksekutif biasanya dipegang oleh lembaga eksekutif yaitu Presiden untuk negara, Gubernur untuk provinsi, Bupati Walikota, untuk Kabupaten/Kota. Tugas lembaga eksekutif menurut doktrin trias politica hanya melaksanakan kebijaksanaankebijaksanaan yang telah digariskan oleh lembaga legislatif serta 
menjalankan Undang-Undang dan Perda yang buat oleh lembaga legislatif. Akan tetapi dalam tahaptahap aplikasinya lembaga eksekutif biasanya memiliki wewenang yang sangat luas dalam ruang geraknya.

Adapun lembaga legislatif adalah suatu badan yang berwenang membuat Undang-Undang. Dalam pengertian yang lain lembaga legislatif bermakna lembaga yang "legislate" atau lembaga pembuat Undang-Undang. Nama lain lembaga legislatif yang sering dipakai ialah parliamen, yaitu suatu istilah yang menekankan unsur bicara (parler) dan merundingkan. Menurut teori yang berlaku rakyatlah yang berdaulat. Rakyat yang berdaulat ini mempunyai suatu "kehendak" (yang oleh Rouseeau disebut volante generale atau general will). Keputusan-keputusan yang diambil oleh badan ini merupakan suara yang authentic dari general will itu. Karena keputusan-keputusannya, baik yang bersifat kebijakan maupun undang-undang, mengikat seluruh masyarakat (Miriam Budiardjo : 2013).

Dengan demikian maka salah satu fungsi legislatif yang terkait dengan eksekutif adalah mengontrol eksekutif dalam arti menjaga supaya semua tindakan eksekutif sesuai dengan kebijaksaaan-kebijaksanaan yang telah ditetapkan.

Menurut Arbi Sanit, ide pembentukan lembaga legislatif pada dasarnya bermula dari keperluan masyarakat akan hukum sebagai sarana mengatur kehidupan bersama disamping kebutuhannya akan badan yang membuat dan memberlakukannya (Arbi Sanit : 2005). Lembaga legislatif dianggap merumuskan kemauan rakyat atau kemauan umum dengan jalan mengartikulasikan dan mengagregasi semua kehendak rakyat ke dalam sebuah produk kebijaksanaan umum (public policy) yang mengikat semua lapisan masyarakat.

Dalam konteks pemerintahan desa, proses terjadinya check and balance antara lembaga eksekutif Kepala Desa dan lembaga legislatif Badan Permusyawartan Desa (BPD) mutlak diperlukan. Artinya dalam melaksankan pemerintahan desa diperlukan keseimbangan kekuatan antara kedua lembaga tersebut. Kedua lembaga tersebut tidak boleh ada yang terlalu kuat dan terlalu lemah. Karena jika itu terjadi proses penyelengaraan pemerintahan desa akan bejalan tidak efektif sehingga sulit untuk mencapai tujuan negara.

Di Kabupaten Pandeglang Provinsi Banten, kondisi Badan Permusyawaratan Desa (BPD) tidak jauh berbeda dengan dengan Badan Permusyawaratan di Desa di Indonesia secara umum yaitu kondisinya masih lemah dalam menjalankan fungsi pemerintahan desa jika dibandingkan dengan kepala desa.

Lemahnya BPD di Kabupaten Pandeglang disampaikan oleh Asep Muslim, akademisi Universitas Mathla'ul Anwar Banten, pada acara Kajian Publik Pusat Studi Politik dan Pemerintahan (PSPP) FISIP UNMA dengan tema Kesiapan Desa di Pandeglang dalam Implementasi Undang-Undang Nomor 6 Tahun 2014 Tentang Desa, : "dengan hadirnya UndangUndang No 6 tahun 2014 Tentang Desa saat ini, sebaiknya masyarakat dan 
pemerintah desa tidak hanya sibuk dengan persiapan turunnya Anggaran Dana Desa (ADD) yang mencapai milyaran rupiah, tapi yang lebih penting melakukan penguatan kelembagaan pemerintah desa, khususnya lembaga Badan Permusyawartan Desa (BPD)yang kenyataanya di Kabupaten Pandeglang masih lemah"(Asep Muslim : 29 September 2014)

Salah satu desa di Kabupaten Pandeglang yang kondisi Badan Permusyawartan Desa (BPD) masih lemah adalah Desa Tegalwangi Kecamatan Menes. Oleh karena itu untuk menyikapi masalah ini diperlukan identifikasi faktor-faktor yang menyebabkan lemahnya Badan Permusyawaratan Desa Tegalwangi Kecamatan Menes Kabupaten Pandeglang melalui penelitian. Penelitian ini diharapkan akan menjadi bahan informasi bagi para pengambil kebijakan dalam rangka melakukan penguatan kelembagaan pemerintah desa khususnya Badan Permusyawaratan Desa (BPD) di Indonesia yang secara umum masih lemah

Tulisan ini bertujuan untuk mengetahui faktor-faktor yang melemahkan Badan Permusyawaratan Desa Tegalwangi Kecamatan Menes Kabupaten Pandeglang dalam melaksankan fungsi pemerintahan desa.

\section{METODE PENELITIAN}

Penelitian ini mengunakan metode deskriptif dengan pendekatan kulaitatif. Metode deskriptif menurut Whitney adalah pencarian fakta dengan interpretasi yang tepat.
Penelitian deskriptif mempelajari masalah-masalah dalam masyarakat, serta tata cara yang berlaku dalam masyarakat serta situasi-situasi tertentu, termasuk tentang hubungan, kegiatan-kegiatan, sikap-sikap, pandangan-pandangan, serta prosesproses yang sedang berlangsung dan pengaruh-pengaruh dari suatu fenomena(dalam Moh Nazir : 2005). Sedangkan Pendekatan kualitatif dalam hal ini sesungguhnya adalah prosedur penelitian yang menghasilkan data-data deskriptif berupa kata-kata tertulis atau lisan dari orang-orang dan prilaku yang dapat diamati (Maleong :1994).

Data penelitian ini diperoleh melalui observasi, wawancara, dan studi pustaka. Observasi dilakukan dengan melihat kondisi kantor, fasilitas, peralatan kerja, dan aktivitas atau kegiatan-kegiatan BPD Desa Tegalwangi. Wawancara dilakukan kepada informan yaitu anggota Badan Permusyawaratan Desa (BPD) Tegalwangi, Kepala Desa Tegalwangi, Sekretaris Desa Tegalwangi, Tokoh masyarakat Tegalwangi, akademisi, dan pejabat Badan Pemberdayaan dan Pemerintah Desa (BPMPD) Kabupaten Pandeglang. Sementara itu studi pustaka dilakukan dengan penelaahan referensi atau dokumen seperti Undang-Undang Desa, Peraturan Daerah Tetang Desa, buku-kuku yang berakitan dengan pemerintah desa, Rencana Pembangunan Jangka Menengah Desa (RPJMDes) Tegalwangi, APBDes Tegalwangi, Surat Keputusan, dan dokumentasi lainnya yang berkaitan dengan pemerintahan desa Tegalwangi. Setelah data terkumpul dilakukan analisis data 
secara induktif dengan tahapan reduksi data, penyajian data, verifikasi data, dan kemudian diambil kesimpulan (Miles Huberman : 2007).

\section{HASIL DAN PEMBAHASAN}

1. Gambaran Lemahnya BPD Desa Tegalwangi

Badan Permusyawaratan Desa (BPD) Tegalwangi Kecamatan Menes Kabupaten Pandeglang terdiri dari lima orang anggota. Anggota BPD Tegalwangi tersebut terpilih secara depinitif pada tahun 2014 berdasarkan musyawarah mufakat dari perwakilan masing-masing daerah pemilihan, yaitu Kampung Karang Mulya, Kampung Tegalwangi, Kampung Leuweung Kolot, Kampung Sawah, dan Kamapung Koranji yang jumlah pendudnya secara keseluruhan berjumlah 2.757 jiwa. (RPJMDes Tegalwangi 2015-2020)

Badan Permusyawaratan

Desa (BPD) Tegalwangi disahkan melalui Surat Keputusan Bupati Pandeglang Nomor 141.2/Kep.23Huk/2014 Tentang Peresmian/Pengesahan Anggota Badan Permusyawaratan Desa Di Wilayah Kabupaten Pandeglang Periode Masa Bhakti Tahun 20142020. Dalam Surat Keputusan tersebut dinyatakan bahwa Badan Permusyawartan Desa agar segera melaksanakan tugas atau pekerjaanya dengan penuh rasa tanggungjawab sesuai dengan batas kewenangan yang telah diatur dengan ketentuan yang berlaku.

Berdasarkan Undang-Undang Nomor 6 Tahun 2014 Tentang Desa, dan Peraturan Daerah (Perda) Kabupaten Pandeglang Nomor 2
Tahun $2015 \quad$ Tentang

Penyelanggaraan Desa, BPD memiliki fungsi menyelenggarakan pemerintahanan desa yaitu sebagai berikut :

1.Membahas dan Menyepakati Rancangan Peraturan Desa Bersama Kepala Desa

2.Menampung dan Menyalurkan Aspirasi Masyarakat Desa; dan

3.Melakukan Pengawasan Kinerja Kepala Desa

Pada kenyataanya dalam menjalankan fungsi tersebut Badan Permusyawartan Desa (BPD) Tegalwangi kecamatan Menes Kabupaten Pandeglang masih lemah seperti yang tergambar dalam uraian berikut ini:

1.1 Lemah dalam membahas dan menyepakati Rancangan Peraturan Desa (Perdes) bersama kepala desa

Dalam hal fungsi membahas dan menyepakati rancangan Peraturan Desa (Perda) bersama kepala desa, BPD Tegalwangi baru dapat membahas dan menyepakati Perdes APBDes dan RPJMDes yang regular harus ada.

Menurut kepala desa Tegalwangi Kiki Maulana Sepa, BPD Tegalwangi bersama-sama dengan kepala desa sudah melaksanakan fungsi pemerintahan desa dalam hal menyusun kebijakan Perdes seperti yang diutarakannya berikut ini :

"Kami (Kepala Desa dan Perangkat Desa) dan BPD Desa Tegalwangi setiap tahun sudah mengadakan pertemuan untuk membahas Peraturan Desa seperti RAPBDes, dan APBDes. Kita musyawarahkan itu secara 
bersama-sama, apa saja kirakira yang disetujui kegiatan/program

pembangunan yang akan dibiayai oleh APBDes" (Wawancara Kepala Desa Kiki Maulana Sepa, 3 Oktober 2016)

Sementara itu terkait dengan fungsi menyusun Peraturan Desa (Perdes), Ketua BPD Tegalwangi Hedi Suhaedi mengatakan :

"Meskipun BPD seperti lembaga legislatif desa, tapi tidak bisa bekerja layaknya anggota DPR atau DPRD yang dalam melaksankan tugasnya yang harus melalui mekanisme atau tahapantahapan tertentu. Seperti menyusun Peraturan desa, itu kan harus beberapa kali rapat, dan diparipurnakan. Tahapan tersebut tidak bisa terjadi sepenunya seperti sidang-sidang komisi, atau rapat pleno seperti di DPRD. Karana sarana pendukung dan anggaran terbatas. Akhirnya kita berusaha bekerja apa adanya sesuai dengan kemampuan kita yang penting kita sudah melaksankan tugas dan fungsi kita." (Wawancara Hedi Suhaedi, 6 Oktober 2016)

Lebih lanjut Ketua BPD Tegalwangi Hedi Suhaedi mengatakan:

“ Biasanya Perdes diusulkan, dibuat oleh kepala desa, kita tinggal menandatangan saja. Dan kita belum bisa menyusun Perdes yang banyak. Kalau menyusun Perdes kita lakukan seperti Perdes APBDes, atau RPJMDes meskipun tidak sebagimana mestinya seperti melalui tahapan-tahapan rapat-rapat pleno. Ini karena keterbatasan kita, kalau ada rapat-rapat banyak menguras anggaran”. Sementara anggaran untuk itu terbatas, bahkan tidak ada" (Wawancara Hedi Suhaedi, 6 Oktober 2016)

Setelah dilakukan pengecekan terhadap keberadaan kebijakan seperti Peraturan Desa (Perdes) di desa Tegalwangi hanya ditemukan Perdes tentang APBDes dan RPJMDes yang sifatnya regular setiap tahun yang harus ada sebagai syarat pencairan Anggaran Dana Desa dari pemerintah. Itupun bentuk dan isinnya sederhana, kurang sistematis tidak seperti Perda yang ada di Kabupaten atau Provinsi. Minimnya kebijakankebijakan yang ada di desa Tegalwangi menunjukan bahwa pemerintah desa termasuk BPD masih lemah dalam hal menghasilkan kebijakan desa. Padahal di desa Tegalwangi banyak masalah seperti tidak dimilikinya Pendapatan Asli Desa (PADes) sehingga APBDes Tegalwangi masih mengalami ketergantungan kepada pemerintah.

Menurut Ade Sudirman, Dosen Ilmu Pemerintahan Universitas Mathla'ul Anwar Fakultas Ilmu Sosial dan Ilmu Politik

“Anggota BPD belum bisa membuat kebijakan seperti Perdes yang baik, karena 
membuat kebijakan itu bukan pekerjaan sederhana, harus dibuat oleh orang-orang yang berkompeten memiliki keahlian konseptual dan teknis yang memadai. Sementara itu anggota BPD biasanya pendidikannya hanya SMU atau SMP yang kemampuannya belum bisa sampai menyusun Perdes. Itulah menurut saya mengapa Perdes di desa itu jarang atau bakhan tidak ditemukan kecuali yang sifatnya regular seperti Perdes APBDes (Wawancara Ade Sudirman, 20 Oktober 2016)

\subsection{Lemah dalam menampung dan menyalurkan aspirasi masyarakat desa \\ Dalam melaksanakan fungsi} menampung dan menyalurkan aspirasi masyarakat desa, BPD Desa Tegalwangi baru dapat menyelenggarakan Musrenbang (Musyawarah Rencana Pemangunan Desa) setiap tahun.

Menurut Yakub, Sekdes Desa Tegalwangi untuk Musyawarah Rencana Pembangunan Desa (Musrenbang) dilakskan oleh BPD setiap tahunnya yang hasil Musrenbang itu dijadikan dasar menyusun Rencana Anggaran Pendapatan dan Belanja Desa (RAPBDes). (Wawancara Yakub 15 Oktober 2016)

Di lain fihak Ketua BPD Tegalwangi Edi Suhaedi mengungungkapkan :

"kami sudah melaksanakan kegiatan menampung aspirasi masyarakat baik itu melalui jalur formal seperti
Musrenbang, maupun informal, tetapi tentunya tidak semua kita tampung karena keinginan masyarakat berbeda-beda dan banyak." (Wawancara Edi Suhaedi15 Oktober 2016)

Berbeda dengan Ketua BPD, menurut salah satu tokoh masyarakat desa Tegalwangi KH Bai Mamun, pemerintah desa Tegalwangi untuk sosialisasi dan undangan mengenai program pembangunan desa masih kurang, seperti yang diutarakannya berikut ini :

"Saya pernah diundang ke kantor desa Tegalwangi dalam rangka kegiatan mahahsiswa Budiluhur Jakarta yang KKN di desa Tegalwangi. Tetapi kalau diundang dalam rangka membicarakan atau musyawarah desa pada masa Kepala Desa yang sekarang belum pernah. Oleh BPD misalnya, belum pernah juga diajak atau diundang untuk merencanakan pemerintah desa. Jadi kalau saya ditanya mengenai pembangunan desa Tegalwangi, saya tidak tahu mengenai program pembangunan desa yang sekarang itu apa saja" (Wawancara KH Bai Mamun, 19 Oktober 2016)

Lebih lanjut KH. Bai Mamun mengutarakan :

"Sebenarnya saya ada unekunek sih, mengenai pembangunan, seperti pemanfaatan tanah kosong yang ada di desa itu bagaimana, harus diapakan?. 
Kemudian saluran air. harusnya itu diatur dengan Peraturan Desa. J Jadi saya sekarang tidak tahu $B P D$ punya rencana apa?, mau membangun apa?, lokasinya dimana?, saya tidak tahu. Harapan saya pemerintah desa Tegalwangi dalam menyelenggarakan pemerintahan dan melaksanakan pembangunan harus sesuai dengan aturan yang sudah ditetapkan." (Wawancara KH Bai Mamun, 19 Oktober 2016 )

Sementara itu warga masyarakat Desa Tegalwangi yang lain yaitu bapak Aak mengungkapkan :

"Saya kurang melihat adanya upaya dari BPD untuk menyaring aspirasi masyarakat. Meskipun secara pribadi saya kenal dengan beberapan anggota BPD. Bahkan ada anggota BPD yang pernah main ke rumah saya. Menurut saya yang terpenting adalah adalah transparansi penyelengaraan pemerinathan dan pembangunan desa. Sekarang ini masayarakat kan sudah tahu bahawa ada anggaran yang turun ke desa mencapai milyaran.

Harusnya

program-program

pembangunan desa itu disosialisasikan. Misalaya bisa dicetak spanduk kecil di pos ronda ditempel/dipasang di setiap kampung programnya, apa saja dan berapa anggaraanya supaya masayarakat bisa tahu seтиа. Masyarakat sebetulnya banyak juga yang ingin tahu tentang pembangunan desa Tegalwangi di pemerintahan yang baru ini."'(Wawancara Aak, 20 Oktober 2016)

Dengan demkian BPD Desa Tegalwangi dalam menjalankan fungsi ini baru sebatas pertemuan formal dan belum dapat menapung dan menyalurkan sepenuhnya aspirasi atau keinginan masyarakat. Kenyataanya masyarakat desa Tegalwangi menginginkan adanya sosialisasi program pembangunan desa, dan transparansi penggunaaan anggaran, yang pada kenyataanya masyarakat desa Tegalwangi belum tahu dan mereka ingin tahu mengenai program pembangunan yang dilakukan oleh pemerintah desa Tegalwangi selama ini.

\subsection{Lemah dalam melakukan pengawasan kinerja kepala desa}

Dalam hal melakukan pengawasan terhadap kinerja kepala desa, BPD Tegalwangi mengatakan sudah berupaya melakukannya seperti yang diutarakan Ketua BPD Hedi Suhaedi berikut ini :

"Kita melakukan kontrol sesuai dengan fungsi kita, tetapi tidak sampai detail. Misalnya kita tahu akan ada pembagunan sarana fisik, kemudian dalam pelaksanaanya kita kontrol apakah dilaksankan. Kalau dilaksankan berarti benar dilaksankan. Tetapi kita tidak sampai memeriksa bahanbahan yang digunakan bangunan tersebut sudah pas 
takarannya".(Wawancara

Hedi Suhaedi, 6 Oktober 2016)

Ketika ditanya mengenai kinerja kepala desa dan masalah penyimpangan yang ada di desa, Hedi Suhaedi mengungkapkan :

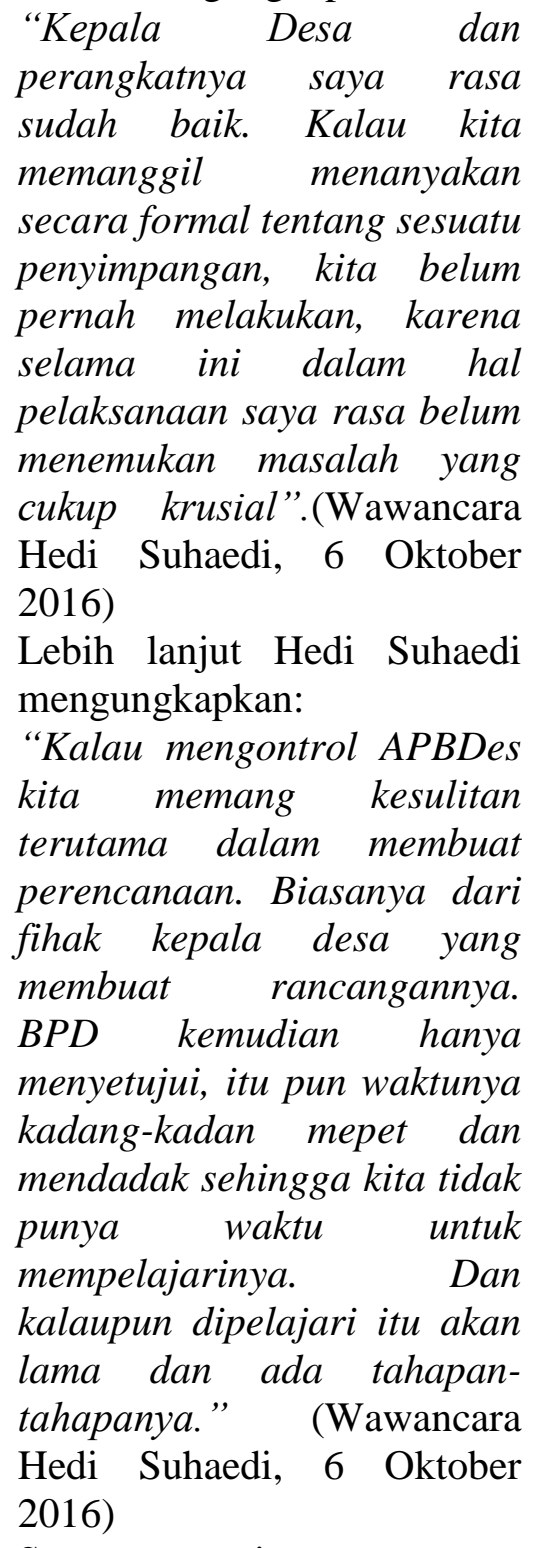

Sementara itu pengamat pemerintahan desa yang juga Dosen Ilmu Pemerintahan Fakultas Ilmu Sosial dan Ilmu Politik Universitas Mathla'ul Anwar Ade Sudirman mengungkapkan :
"Selama ini yang saya tahu anggota BPD itu masih terkesan dibawah subordinat kepala desa, mengapa demikian? Karena Biasanya anggota BPD yang terpilih itu adalah orang-orang dekat atau kepercayaan kepala desa. Mereka juga biasanya merupakan tim sukses dari kepala desa ketika Pemilihan Kepala desa, sehingga tidak benar-benar melakukan kontrol/pengawasan terhadap Kepala Desa. Apalagi selama ini dalam prakteknya BPD berkantor di kantor kepala desa bersama-sama dengan Sekdes dan Perangkat Desa. BPD belum memiliki kantor atau tempat bekerja yang terpisah dengan kepala desa. Sehingga kadang-kadang masyarakat menganggapnya BPD itu bagian dari kepala desa secara

kelembagaan."'(Wawancara Ade Sudirman, 20 Oktober 2016)

Kenyataanya berdasarkan pemantauan selama ini sering ditemukan kantor desa Tegalwangi sering tutup, sudah tidak ada yang bekerja ketika waktu sesudah dzuhur jam 14.00. Padahal menurut waktu kerja, jam tersebut seharusnya kantor desa masih harus buka melaksanakan aktivitasnya terutama dalam melayani masyarakat.

\section{Faktor-Faktor Penyebab Lemahnya BPD Desa Tegalwangi Dalam Melaksankan Fungsi Pemerintahan Desa}


Berdasarkan paparan yang sudah disampaikan sebelumnya bahwa kondisi BPD Tegalwangi masih lemah dalam melaksanakan fungsinya. Lemahnya Badan Permusyawaratan desa Tegalwangi dalam melaksanakan fungsi pemerintahan desa ternyata disebabkan oleh faktor-faktor sebagai berikut:

\subsection{Kapasitas Sumber Daya Manusia BPD yang lemah} Anggota BPD Desa Tegalwangi berjumlah lima orang yang merupakan perwakilan dari 7 kampung desa Tegalwangi. Mereka terpilih berdasarkan hasil pemilihan dan musyawarah masing-masih kampung tersebut. Kelima orang anggota BPD Tegalwangi itu sebagai berikut : Hedi Suhaedi, Abu Bakar, Ahmad Dasuki, Salim, dan Nana Sudiana. Dengan lima orang anggota tersebut terbentuk struktur organisasi BPD Desa Tegalwangi dengan komposisi sebagai berikut : Ketua Hedi Suhaedi, Wakil Ketua Abu Bakar, Sekretaris Ahmad Dasuki, Anggota Salim dan Nana Sudiana

Tetapi dalam struktur organisasi BPD yang dibentuk ini tidak dilengkapi dengan bidang kerja seperti komisi-komisi di DPRD. Sehingga tidak diketahui dengan jelas pembagian kerja dari masingmasing anggota BPD Tegalwangi.

Untuk melihat kemampuan sumber daya manusia BPD Tegalwangi, dengan melihat profil atau riwayat hidup singkat anggota BPD Tegalwangi sebagai berikut :

Hedi Suhaedi, lahir di Pandeglang 22 Jini 1974 merupakan anggota BPD Tegal wangi perwakilan dari daerah/kampung
Tegalwangi RT01/RW04. Menjadi Anggota BPD sudah 2 periode, yaitu periode tahun 2008-2014 hingga 2014 sampai dengan sekarang. Pendidikan terakhirnya Sekolah Lanjutan Tingkat Atas (SLTA) Menes yang ditamatkan tahun 1990. Hedi Suhaedi merupakan Ketua BPD Desa Tegalwangi memiliki satu orang istri dan 3 orang anak. Ia terpilih sebagai ketua BPD berdasarkan musyawarah. Selain menjabat Ketua BPD, kegiatan sehari-hari lainya ia aktif di Kelompok Penyanyi Jalanan (KPJ) Kabupaten Pandeglang.

Abu Bakar, lahir di Pandeglang 1968, merupakan anggota BPD Desa Tegalwangi perwakilan dari kampung Karang Mulya RT. 02/RW02. Menjadi anggota BPD sejak tahun 2014 sampai sekarang. Pendidikan terakhirnya Sekolah Lanjutan Tingkat Pertama (SLTP) yang ditamatkan tahun 1989. Abu Bakar merupakan Wakil Ketua BPD Desa Tegalwangi, memiliki satu orang istri dan 3 orang anak. Ia terpilih menjadi anggota BPD berdasarkan musyawarah dan menjadi Wakil Ketua BPD berdasarkan musyawarah. Selain menjabat sebagai Wakil BPD, kegiatan atau pekerjaan lainnya sebagai petani ladang dan sawah.

Salim, lahir di Pandeglang 1974. Merupakan anggota BPD Desa Tegalwangi perwakilan dari kampung sawah. Menjadi anggota BPD sejak tahun 2014 hingga sekarang. Pendidikan terakhirnya Sekolah Lanjutan Tingkat Atas (SLTA) yang di tamatkan tahun 1992. Salim merupakan Anggota BPD berdasarkan musyawarah. 
Selain menjadi anggota BPD kegiatan atau pekerjaanya sebagai seorang pedagang.

$\begin{array}{lcr}\text { Ahmad Dasuki, lahir di } \\ \text { Pandeglang } 18 \text { Juni } 1979 . \\ \text { Merupakan anggota } & \text { BPD } \\ \text { Tegalwangi perwakilan dari } \\ \text { kampung Kacapi Amis RT03/RW06. } \\ \text { Menjadi anggota BPD sejak tahun } \\ 2014 \text { hingga sekarang. Pendidikan } \\ \text { terakhir Ahmad Dasuki Diploma } \\ \text { Tiga (D3) Universitas Komputer } \\ \text { Bandung tamat tahun 2003. Ahmad } \\ \text { Dasuki merupakan anggota BPD } \\ \text { terpilih berdasarkan musyawarah. } \\ \text { Selain sebagai anggota BPD, } \\ \text { pekerjaan Ahmad Dasuki pengusaha } \\ \text { Warung Internet (Warnet) di } \\ \text { desanya. }\end{array}$

Nana Sudiana, lahir di Pandeglang 7 Oktober tahun 1979. Merupakan anggota BPD Desa Tegalwangi Perwakilan kampung Karang Mulya RT 02/RW01. Pendidikan terakhir Nana Sudian Sarjana (S1) Fakultas Ekonomi Universitas Mathla'ul Anwar. Nana Sudiana merupakan anggota BPD yang terpih melalui musyawarah. Selain sebagai anggota BPD Nana Sudiana bekerja pengusaha Baja Ringan/Bangunan, dan usaha penjualan ikan.

Dengan melihat profil tersebut anggota BPD Tegalwangi secara kompetensi akan sulit untuk bisa bekerja menjalankan fungsinya secara profesional karena terkendala pendidikan dan kesibukan kerja masing-masing anggota BPD. Kemudian berdasarkan wawancara mendalam anggota BPD yang lebih banyak memahami tugas dan fungsi BPD baik itu konsep maupun teknis atau praktek Ketua BPD Edi Suhaedi. Sedangkan yang lainnya kurang dapat memahami tugas dan fungsi BPD. Hal ini karena Ketua BPD pernah menjadi anggota BPD pada periode sebelumnya. Ketua BPD juga pernah mengikuti pelatihan anggota BPD Badan Pemberdayaan dan Pemerintahan Desa Kabupaten Pandeglang. Sedangkan anggota BPD lainnya belum pernah mengikuti pelatihan tersebut.

Mereka (anggota BPD Desa Tegalwangi) mengakui dengan sumber daya yang ada saat ini sangat sulit untuk berkerja ideal sebagaimana yang diamanatkan dalam Undang-Undang seperti yang tergambar dalam kutipan wawancara berikut ini :

"Jadi kita berkerja apa adanya sesuai dengan kemampuan kita. Makanya kita siasati kehadiran kita di desa itu kita jadwal piket, karena tidak mungkin kita setiap hari harus ke kantor desa, karena kita punya kesibukan lain mencari sumber penghidupan yang lain. Keinginan kita ada pelatihan semacam Bimtek mengenai tugas dan fungsi BPD agar kita juga semua angota BPD meningkat kemampuannya, jangan hanya ketua BPD saja yang diikutkan dalam Bimtek BPD." (Wawancara Angggota BPD : 27 Agustus 2016)

\subsection{Sarana pendukung kerja BPD kurang memadai}

Bagaimanapun ketersediaan sarana untuk bekerja sangat menentukan dan berpengaruh terdapa 
kinerja seorang dalam sebuah lembaga, termasuk pada Badan Permusyawaratan Desa (BPD) Tegalwangi yang merupakan lembaga pemerintah desa.

Berdasarkan pemantauan di lapangan, Badan Permusyawaratan Desa (BPD) Desa Tegalwangi tidak memiliki kantor sendiri. Kantor BPD desa Tegalwangi hanyalah sebuah ruangan yang berukuran empat kali tiga meter (duabelas meter persegi). Kantor kerja BPD Tegalwangi berada di dalam gedung atau kantor kepala desa yang bersebelahan dengan ruangan perangkat desa seperti kantor Kepala Urusan Desa desa Tegalwangi. Di dalamnya hanya ada satu meja kerja dan empat kursi yang berdempetan, diatas meja kerja terdapat satu unit Komputer dan Printer. Di salah satu sudut dingding terdapat gambar bagan struktur organisasi Badan Permusyawaratan Desa (BPD) Tegal Wangi dan Peta Desa Tegalwangi.

Jika melihat dari ukuraanya saja ruang kerja BPD tidak cukup untuk menapung lima orang anggota BPD. Sebagimana yang diutarakan Nana Sudiana, salah satu anggota BPD Tegalwangi berikut ini

"runganan kerja kita
memang tidak cukup untuk
menerima tamu atau
masyarakat yang ingin
bertemu dengan kita.
Jangankan untuk menerima
masayarakat, untuk kita
rapat saja tidak cukup. Bapak
bisa lihat sendiri. Jika ada
tamu biasanya kita terima di
aula kecil kantor desa. Tetapi
meskipun begitu kita tetap
bisa bekerja" (Wawancara
Nana Sudiana 15 Juli 2016)

Di fihak lain merespon kehadiran anggota BPD, Sekretaris Desa (Sekdes) Tegalwangi Yakub mengungkapkan :

"Tidak setiap hari anggota BPD dapat hadir di kantor desa. Mereka bekerja dijadwal bergiliran antara 2 sampai 3 orang setiap harinya. Anggota BPD bisa hadir semua jika ada rapat atau pertemuan besar seperti misalnya pada acara Musrenbang Desa (Wawancara Yakub, 15 Juli 2016)

Pernyataan Sekdes Desa Tegalwangi itu dibenarkan oleh Ketua BPD Tegalwangi Hedi Suhaedi bahwa mereka (anggota BPD) tidak bisa setiap hari semuanya hadir bekerja di kantor :

"Setiap hari memang selalu ada anggota BPD yang hadir ke kantor dengan di jadwal setiap harinya ada dua orang anggota BPD yang pasti ada di kantor. Kecuali Ketua $B P D$ yang setiap hari. Menurut Ketua BPD Hedi Suhadi meskipun kantor kita hanya ruangan seadanya kita tetap berusaha bekerja sesuai dengan tugas dan fungi kita sebagai BPD".(Wawancara Anggota BPD, 15 Juli 2016)

Selain kantor dan perlengkapan desa yang kurang memadai, BPD pun sering kesulitan ketika hendak berkeja di luar atau terjun ke lapangan seperti mengontrol pembangunan ataupun meyaring aspirasi masyarakat.

"Untuk bekerja di lapangan seperti mengawasi pembangunan desa atau 
menyaring aspirasi masyarakat kita kesulitan, karena hanya ada satu sepeda motor dan anggaran yang ada tidak mencukupi untuk bekerja dilapangan. Akhirnya kita kadang-kadang menggunakan uang pribadi seadanya, yang penting kita bisa bekerja" (Wawancara Anggota BPD, 28 Agustus 2016)

\subsection{Pendapatan atau tujangan BPD yang kecil}

Lemahnya BPD Tegalwangi dalam melaksanakan fungsinya dipengaruhi juga oleh jumlah pendapatan atau tunjangan yang mereka peroleh sebagai anggota BPD. Menurut Ketua BPD Edi
Suhaedi besaran pendapatan anggota BPD Desa Tegalwangi adalah sebagai berikut : Untuk tunjangan Ketua BPD 50\% (limapuluh persen) dari gaji kepala desa, tunjangan Wakil Ketua BPD tunjangannya 50 $\%$ (limapuluh prosen) dari tunjangan Ketua BPD, tunjangan Sekretaris BPD $40 \%$ (limapuluh prosen) dari tunjangan Ketua BPD, dan tunjangan anggota BPD $30 \%$ (tiga puluh prosen) dari tunjangan ketua BPD. (Wawancara Ketua Hedi Suhaedi 28 Agustus 2016).

Sebagai bahan perbandingan berikut ini data penghasilan pemerintah desa Tegalwangi yang terdapat dalam dokumen Anggaran Pendapatan dan Belanja Desa Tegal Wangi Tahun Anggaran 2016 :

TABEL PENGHASILAN DAN TUNJANGAN PEMERINTAH DESA TEGALWANGI

\begin{tabular}{|c|c|c|c|c|c|c|c|}
\hline \multirow{2}{*}{$\begin{array}{l}\mathbf{N} \\
\mathbf{O}\end{array}$} & \multirow{2}{*}{$\begin{array}{l}\text { URAIAN } \\
\text { Belanja Pengawai } \\
\text { (2.1.1.1) }\end{array}$} & \multicolumn{4}{|c|}{ VOLUME } & \multirow{2}{*}{$\begin{array}{l}\text { HARGA } \\
\text { SATUAN }\end{array}$} & \multirow[t]{2}{*}{ JUMLAH } \\
\hline & & & & & & & \\
\hline & $\begin{array}{l}\text { Penghasilan Tetap } \\
\text { Kades dan } \\
\text { Perangkat }\end{array}$ & & & & & & \\
\hline 1 & $\begin{array}{l}\text { Penghasilan Tetap } \\
\text { Kades }\end{array}$ & 1 & Org & 5 & Bln & 2.000 .000 & 10.000 .000 \\
\hline 2 & $\begin{array}{l}\text { Penghasilan Tetap } \\
\text { Sekdes }\end{array}$ & 0 & Org & 12 & Bln & 1.400 .000 & \\
\hline 3 & $\begin{array}{l}\text { Penghasilan Tetap } \\
\text { Kaur dan Kasi }\end{array}$ & 3 & Org & 5 & Bln & 1.000 .000 & 15.000 .000 \\
\hline 4 & $\begin{array}{l}\text { Penghasilan Tetap } \\
\text { Kepala Seksi }\end{array}$ & 3 & Org & 5 & Bln & 1.000 .000 & 15.000 .000 \\
\hline 5 & $\begin{array}{l}\text { Penghasilan Tetap } \\
\text { Kepala Dusun }\end{array}$ & 2 & org & 5 & Bln & 1.000 .000 & 10.000 .000 \\
\hline & & & & & & & \\
\hline & $\begin{array}{l}\text { Tunjangan Kades } \\
\text { dan Perangkat }\end{array}$ & & & & & & \\
\hline
\end{tabular}




\begin{tabular}{|l|l|l|l|l|l|l|l|}
\hline 1 & Penghasilan Kades & 1 & Org & 5 & Bln & 550.000 & 2.750 .000 \\
\hline 2 & Penghasilan Sekdes & 1 & Org & 5 & Bln & 400.000 & 2.000 .000 \\
\hline 3 & $\begin{array}{l}\text { Penghasilan Kaur } \\
\text { dan Kasi }\end{array}$ & 6 & Org & 5 & Bln & 300.000 & 9.000 .000 \\
\hline 4 & $\begin{array}{l}\text { Penghasilan Kepala } \\
\text { Kadus }\end{array}$ & 2 & Org & 5 & Bln & 150.000 & 1.500 .000 \\
\hline 5 & $\begin{array}{l}\text { Penghasilan } \\
\text { Bendahara }\end{array}$ & 1 & org & 5 & Bln & 500.000 & 2.500 .000 \\
\hline & Tunjangan BPD & & & & & & \\
\hline 1 & $\begin{array}{l}\text { Tunjangan Ketua } \\
\text { BPD }\end{array}$ & 1 & Org & 5 & Bln & 1.000 .000 & 5.000 .000 \\
\hline 2 & $\begin{array}{l}\text { Tunjangan Wakil } \\
\text { Ketua BPD }\end{array}$ & 1 & Org & 5 & Bln & 500.000 & 2.500 .000 \\
\hline 3 & $\begin{array}{l}\text { Tunjangan } \\
\text { Sekretaris BPD }\end{array}$ & 1 & Org & 5 & Bln & 400.000 & 2.000 .000 \\
\hline 4 & $\begin{array}{l}\text { Tunjangan Anggota } \\
\text { BPD }\end{array}$ & 2 & Org & 5 & Bln & 300.000 & 3.000 .000 \\
\hline & & & & & & & \\
\hline
\end{tabular}

Sumber : Anggaran dan Pendapatan Belanja Desa Tahun Anggaran 2016

Menurut Hedi Suhaedi Ketua BPD desa Tegalwangi, tidak ada pendapatan lagi selain hanya tunjangan bagi anggota BPD. Lebih lanjut Hedi Suhaedi menyatakan bahwa tunjangan tersebut turunnya tidak setiap bulan tetapi biasanya tiga bulan atau per lima bulan. Tunjangan yang diterima anggota BPD sangat jauh perbedaanya jika dibandingkan dengan gaji Sekretaris Desa dan Perangkat Desa seperti Kepala Urusan (Kaur) Pemerintahan yang pendapatannya lebih besar dari tunjangan anggota BPD.

Untuk mencukupi kebutuhan sehari-hari mereka tidak bisa mengandalkan sepenuhnya dari gaji BPD. Semua anggota BPD bekerja selain menjadi anggota BPD. Ada yang berwiraswasta seperti Ahmad Dasuki yang memiliki Warung Internet, Abu Bakar sebagai petani , dan Nana Sudiana pengusaha bangunan rangka baja dan kolam ikan. Sedangkan Hedi Suhaedi Ketua BPD beraktivitas sebagai Ketua Kelompok Pengamen Jalanan (KPJ) Kabupaten Pandeglang

Dengan bercabangnya pekerjaan anggota Badan Permusyawartan Desa (BPD) Tegal wangi akhirnya pekerjaan-pekerjaan sebagai anggota BPD tidak sepenuhnya bisa berjalan karena mereka juga memiliki kesibukan lain bekerja mencari penghasilan untuk mencukupi kebutuhan hidup mereka di tempat lain, seperti diutarakan Hedi Suhaedi berikut ini :

"Dengan pendapatan yang terdapat dalam APBDes sebenarnya itu kurang mencukupupi kebutuhan hidup kita. Akhirnya kita juga terpaksa bekerja atau beraktivitas di tempat lain untuk menutupi kebutuhan 
hidup sehari-hati"

(Wawancara Hedi Suhaedi 28

Agustus 2016)

\subsection{Belum adanya kebijakan yang menguatkan kelembagaan BPD}

Meskipun sudah ada UndangUndang nomor 6 Tahun 2014 Tentang Desa, tetapi UndangUndang tersebut masih umum, belum memberikan dampak signifikan bagi keberadaan Badan Permusyawaratan Desa (BPD) dalam melaksankan fungsinya. Termasuk BPD Tegalwangi masih lemah dalam melaksankan fungsinya.

Menyikapi masalah lemahnya BPD Tegalwangi, Kepala Bidang Pemerintahan Desa Badan Pemerintahan Desa dan Pemberdayaan Masayarakat Desa (BPMPD) Kabupaten Pandeglang Provinsi Banten Mujani Safeudin mengungkapkan :

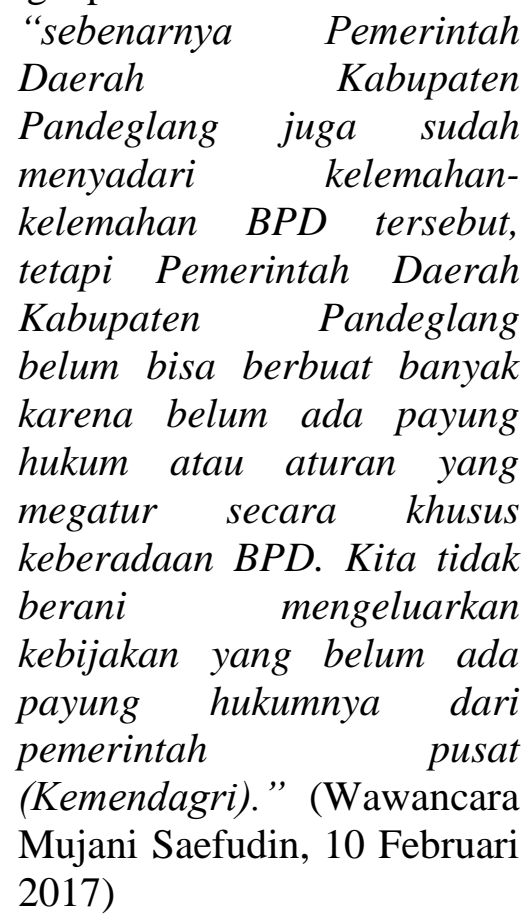

Kemudian dalam menyikapi kecilnya pendapatan BPD, Lebih lanjut Mujani mengungkapkan :

"Semestinya memang tujangan BPD tidak kecil seperti skarang ini, karena bagaimanapun BPD adalah mitra sejajar kepala desa yang sama-sama sebagai penyelenggara pemrintah desa. Tetapi lagi-lagi kebijakan yang ada seperti dalam postur APBDes, pendapatan BPD hanya sebatas tunjangan saja, tidak seperti kepala desa dan perangkat desa yang sudah memiliki gaji tetap dan tunjangan karena aturannya begitu adanya. Selain juga memang fihak Pemda Kabupaten Pandeglang belum memiliki anggaran untuk menambah tunjangan $B P D$ " (Wawancara Saefudin, 10 Februari 2017)

Lebih lanjut Mujani Saefudin menjelaskan :.

"Mengenai Kantor BPD, saya kira di seluruh desa yang ada di Kabupaten Pandegelang belum ada desa yang memilki kantor BPD yang terpisah dari kantor kepala desa. Semuanya masih bergabung dalam kantor desa itu. Sebetulnya boleh-boleh saja membangun Kantor BPD yang tepisah dari kantor kepala desa, tetapi anggaran yang ada dalam APBDes tidak ada peruntukan untuk membangun fasilitas gedung BPD. Tanahnya saja harus merupakan hibah dari 
masyarakat. Jadi pada prinsipnya kita juga ingin melihat BPD itu dapat bekerja secara profesional, tetapi harus ada aturannya. Saya lihat selama ini aturan yang ada seperti Peraturan Pemerintah, Permendagri, atau Perda sekalipun secara teknis atau detail belum mengatur keberadaan BPD. Tidak Seperti Kepala Desa dan Perangkat Desa yang sudah jelas" (Wawancara Mujani Saefudin, 10 Februari 2017)

Dengan demikian apabila dicermati faktor yang melemahkan BPD desa Tegalwangi bukan hanya sumberdaya manusia anggota, sarana pendukung kerja, dan pendapatan BPD yang yang kurang, juga karena di dalam sistem penyelenggaraan pemerintah desa belum adanya kebijakan yang memungkinkan BPD Tegalwangi dapat bekerja seperti Kepala Desa dan Perangkat Desa

\section{KESIMPULAN DAN SARAN}

Berdasarkan uraian yang sudah dipaparkan dalam pembahasan dapat disimpulkan bahwa faktorfaktor yang menyebabkan lemahnya Badan Permusyawaratan Desa (BPD) Desa Tegalwangi Kecamatan Menes Kabupaten Pendeglang Provinsi Banten dalam menjalankan fungsi pemerintahan desa adalah sebagai berikut :

Pertama, kurangnya kapasitas sumber daya manusia Badan Permusyaratan Desa (BPD) Desa Tegalwangi sehingga dalam menjalankan fungsi pemerintahan desa tidak sebaimana mestinya. Kedua, BPD Tegalwangi kurang didukung oleh sarana kerja yang memadai seperti kantor, dan fasilitas atau peralatan kerja, dan alat transportasi. Ketiga, kecilnya pendapatan tujangan anggota BPD, sehingga anggota BPD tidak fokus bekerja karena harus mencari pendapatan lain untuk mencukupi kebutuhan hidupnya. Keempat, belum adanya kebijakan yang menguatkan kelembagaan BPD, sehingga sulit bagi BPD untuk dapat bekerja sesuai dengan fungsinya.

Oleh karena itu dalam rangka menyikapi lemahnya BPD dalam melaksanakan fungsinya seperti yang terjadi di desa Tegalwangi, diperlukan upaya penguatan kelembagaan BPD. Karena bagaimanapun sesuai dengan Undang-Undang Desa, BPD memiliki kedudukan yang setara dengan kepala desa, yaitu sebagai lembaga penyelenggaran pemerintah desa. Penguatan lembaga BPD dapat dilakukan dengan segera disusunnya kebijakan oleh pemerintah atau pemerintah daerah yang dapat mendorong BPD dapat bekerja melaksanakan fungsinya sesuai Undang-Undang Desa.

Isi kebijakan tersebut setidaktidaknya memuat Pertama, dalam merekrut anggota BPD harus lebih selektif dengan mempertimbangan kualifikasi pendidikan, dan pengalaman dalam bekerja, maupun pengabdian di masyarakat desa. Kedua, adanya sarana kerja yang memadai seperti kantor, dan fasilitas kerja lainnya supaya anggota BPD dapat bekerja secara profesional. Terutama Kantor BPD harus terpisah dari gedung kepala desa. Hal ini dilakukan untuk menghilangkan kesan bahwa BPD bagian subordinat 
dari kepala desa. Ketiga, meningkatkan kesejahtraan anggota BPD dengan adanya gaji atau tunjangan yang proporsional, agar tidak ada kesenjangan dengan gaji atau tunjangan kepala desa dan perangkatnya yang diharapkan anggota BPD betul-betul fokus terhadap pekerjaanya sebagai penyelenggara pemerintah desa. Keempat, adanya pelatihan atau bimbingan teknis penguatan kapasitas anggota BPD secara intensif oleh pemerintah atau pemerintah daerah agar anggota BPD benar-benar memiliki kemampuan dalam menjalankan fungsinya sehingga penyelenggaraan pemerintahan dan pelaksanaan pembangunan desa berjalan efektif yang pada gilirannya dapat mempercepat terjadinya kesejahtraan dan kemajuan masyarakat desa

\section{DAFTAR PUSTAKA}

Budiardjo Miriam, 2013. DasarDasar Ilmu Politik. Gramedia. Jakarta

Moleong, J. Lexy 2011. Metode Penelitian Kualitatif. Remaja Rosdakarya. Bandung

Miles B,Matthew dan Huberman (2007), Analisis Data Kualitatif: Buku Sumber Metode-metode Baru, Universitas Indonesia Press, Jakarta.

Nazir Moh. 2005. Metode Penelitian. Ghalia Indonesia. Bogor

Sanit Arbi.2005. Perwakilan Politik Di Indonesia. Rajawali Pers

Undang-Undang No 6 Tahun 2014 Tentang Desa

Peraturan Daerah Kabupaten Pandeglang Nomor 2 Tahun
2015 Tentang Pemerintahan

Desa

Rico Masura. 2014. Pelaksanaan Fungsi Badan Permusyawaratan Desa (BPD) Dalam Penyelengaraan Pemerintahan Desa (Suatu Studi Di Desa Bolangitang Satu Kecamatan Bolangitang Barat Kabupaten Bolaang Mongdow Utara) Jurnal Politico Vol. 1 No. 42014. Bolaang Mongdow Utara.

Sartika Putri Ngadi. 2014. Peran Badan Permusyawatan Desa Dalam Menjalankan Fungsi Pengawasan Pemerintahan Di Desa Lopana Kecamatan Amurung Timur Kabupaten Minahasa Selatan, ejornal.unsrat.ac.id/index.php/j urnaleksekutif

Yuniarni. 2014, Penilaian Kinerja Badan Permusyawaran Desa (BPD) di Desa Risun Kecamatan Lingga Utara Kabupaten Lingga. Universitas Maritim Raja Ahli Haji. ejurnal umrah.ac.id

Anggaran Pendapatan dan Belanja Desa (APBDes) Desa Tegalwangi Kecamatan Menes Kabupaten Pandeglang Tahun Anggaran 2016

Rencana Pembangunan Jangka Menengah Desa (RPJMDes) Tegalwangi Kecamatan Menes Kabupaten Pandeglang

Surat Keputusan Bupati Pandeglang

Nomor 141.2/Kep.23-

Huk/2014 Tentang

Peresmian/Pengesahan

Anggota Badan

Permusyawaratan Desa Di Wilayah Kabupaten 
Pandeglang Periode Masa

Bhakti Tahun 2014-2020 